\title{
GEOGRAPHICAL INDICATIONS AS AN ALTERNATIVE TO SAVE THE POTENTIAL PRODUCT OF MICRO, SMALL AND MEDIUM ENTERPRISES (MSMES') IN SRAGEN REGENCY
}

\author{
Triyono Adi Saputro \\ Universitas Sebelas Maret Surakarta \\ Email:3ada.as@gmail.com \\ Yudho Taruno Muryanto \\ Universitas Sebelas Maret Surakarta \\ Email: yudho_fhuns@yahoo.com

\section{Suraji} \\ Universitas Sebelas Maret Surakarta \\ Email: suraji.sh@gmail.com
}

\begin{abstract}
This research was conducted as an effort to analyse the MSMEs' products of Sragen Regency which have not been known and have the potential to be granted legal protection through geographical indications. This research is an empirical legal research with primary and secondary legal basic materials. The research location was carried out in Kalijambe Sub-district with data collection techniques through literature study and direct interviews with local governments and businessmen in Sangiran. The result of the research is that in Sragen Regency, there is a product which can be categorized as geographical indication and has good prospects for the long term and is able to maintain the reputation of the existing area in Sragen. The product is Sangiran's fossil stone handicraft, which is a potential superior product to be registered through geographical indications, so that registration with geographical indications can be used as an effort to save potential MSMEs' products in Sragen Regency by the fossil stone handicrafts in Kalijambe Sub-district. This effort is also a form of legal protection for superior regional products of Sragen Regency in accordance with the mandate of Sragen Regency Regional Regulation Number 3 Year 2013 concerning MSMEs.
\end{abstract}

Keywords: Geographical Indication; Product Saving; MSMEs

\section{INTRODUCTION}

Sragen Regency is one of the areas in Central Java Province which is located between the borders of East Java Province at the eastern end. The area which is famous for its "Sragen Asri" motto has a lot of excellent potentials that are spread in several districts with a variety of different products. ${ }^{1}$ The superior products in Sragen Regency are the original masterpieces of MSMEs actors who are very creative and innovative. Some of the products that are produced and capable of being excellent in Sragen Regency are the products of written batik, beber puppets (a type of Indonesian puppets which is shown not in the form of a shadow image but a picture show), and fossil stone crafts. Besides,

\footnotetext{
${ }^{1}$ Badan Pusat Statistik (BPS), 2020, Sragen Dalam Angka Tahun 2020 (Sragen Regency in Figures), Badan Pusat Statistik (BPS) Press, Sragen.pg 3-4
} 
there are still many products produced by MSMEs actors in Sragen area but not regional superior products, such as convection products, bricks, processed food and many more.

The existence of regional MSMEs actors is actually able to make a big contribution to the regions, government, and local communities in Sragen Regency. They do not only contribute to regional per capita income, but also have another positive impact that can be felt by many parties, by reducing regional unemployment and poverty. This kind of condition should be continuously supported and considered by stakeholders and local government so that the existence of business actors in the regions can continue to develop and progress more rapidly so that the regional business actors in Sragen can compete in both national and international markets.

As a milestone in the regional economy, MSMEs actors in Sragen Regency are very enthusiastic about the Sragen area, because the development of the number continues to increase every year. For Sragen Regency, the number of MSMEs actors per 2020 is 68,351 business actors. ${ }^{2}$ This development is divided into the scale of the number of micro, small and medium entrepreneurs with a variety of products produced and spread in the Sragen district. Various products are produced, which are not only processed food, convection, handicrafts, bricks, and others.

The development of the number of MSMEs actors in Sragen Regency continues to increase but is not matched by the number of legality registered. This can be seen from the number of MSMEs actors in Sragen Regency who have been registered and licensed in the period 2020 which amount to 4,994 business actors. ${ }^{3}$ This condition shows that awareness of the importance of law legality is still very low and cannot be fully understood on the true essence of business legality compared to the number of MSMEs per 2020, that is about 68,351 business actors.

This situation arises due to various problems that develop in the community, not only from one party but also many things that cause MSMEs actors in Sragen Regency to experience delays in processing legality or licensing for the products they produce. Based on the results in the field, the problem faced is that human resources are still low, because not all business actors have a high level of education so that it is still difficult to absorb new information, the government has not fully paid more attention to MSMEs actors so that information is less fully absorbed by business actors, and there are still many the local stakeholders who close their eyes to the existence of MSMEs that really need guidance, assistance, and counseling for the long-term sustainability of their businesses.

The lack of legal awareness of MSMEs actors of Sangiran's fossil crafts is the main key to date regarding these products that cannot be registered for legal protection

\footnotetext{
${ }^{2}$ The Results of Interview with Supat, SE as the Section Head of Cooperative Division, Cooperative Service and MSME, Sragen Regency, September $1^{\text {st }}, 2020$.

${ }^{3}$ The Results of Interview with Suhari, SH as the Section Head of Licensing at the Office of One-Door Integrated Investment Service, Sragen Regency, September $3^{\text {rd }}, 2020$.
} 
through geographical indications. This arises because of the limited human resources (HR) of the region and the lack of socialization from the local government regarding the geographical indication rules that have been applied so far as a whole to MSMEs in Sragen Regency. ${ }^{4}$ This situation ultimately has resulted in Sragen Regency experiencing delays in processing the legality of MSMEs businesses related to geographical indications. So it is not surprising, if Sangiran's fossil crafts of MSMEs cannot fully understand the scheme of the registration process for business legality with clear geographical indications and get legal protection for Sangiran's fossil handicraft products through geographical indications.

The role of legal protection for legality is very vital for the life of MSMEs actors in the region, which are often forgotten and ignored by business actors even though they have very large impacts on the success of businesses in both national and international trades. The large number of regional products that are developing in Indonesia, are well known by the public, and have added value produced, should be followed by legal protection to avoid fraudulent competition in trade. ${ }^{5}$ This should be instilled since the beginning of starting a business, for the sake of business smoothness and product safety when sold in the markets outside Sragen Regency.

One form of legal protection that can be provided to MSMEs actors in Sragen Regency is through Intellectual Property Rights (IPR) specifically for geographical indications (GI). Some of the reasons are because Sragen Regency has potential products that can be protected by geographic indication (GI) of Sangiran's fossil stone handicrafts which are located in Kalijambe Sub-district Sragen Regency with 60 business actors. ${ }^{6}$ These MSMEs handicraft products have special and unique characteristics, seen from the raw materials used and craftsmen who come from some areaa around Sangiran. This is in accordance with Article 1 paragraph 6 of Law Number 20 of 2016 concerning Trademarks and Geographical Indications, in which geographical indication products (GI) are formed due to natural factor, human factor, and the combination of those.

The novelty in this research is that the researcher examines the problems existing in MSMEs of Sangiran's fossil handicrafts by conducting a direct survey in the field from the point of view of jurisprudence related to the legality of geographical indication business. So far, there has been no researcher who has discussed the existence of MSMEs of Sangiran's fossil handicrafts in Sragen Regency in detail and in depth related to the legality aspects of geographical indication business. Given the importance of legal protection through geographical indications for MSMEs' products, the researcher is interested in examining the problems that exist in Sragen so that the MSMEs' products

\footnotetext{
${ }^{4}$ The Results of Interview with Sukoco as MSMEs actor in Sangiran, Kalijambe District, Sragen Regency, December $3^{\text {rd }}, 2020$.

${ }^{5}$ Saky Septiono, 2009, Perlindungan Indikasi Geografis dan Potensi Indikasi Geografis Indonesia, Subdit Indikasi Geografis Dijten HKI ; Kementerian Hukum dan HAM RI, Jakarta, pg. 1

${ }^{6}$ The Results of interview with Bambang as the Head of Association Cooperative, Sragen MSMEs, Kalijambe Sub-district, Sragen Regency, on September $14^{\text {th }}, 2020$
} 
in Sragen Regency can be guaranteed for their existence and safety of MSMEs products. Sangiran's fossil crafts can be saved from unfair and fraudulent business competition.

This research focuses on analyzing the potential of MSMEs' products in Sragen regency, considering the potential that can be protected by geographical indications through fossil stone handicrafts in Kalijambe Sub-district, Sangiran. This type of research is empirical legal research with primary and secondary legal basic materials. The research was conducted in Kalijambe Subdistrict, Sragen Regency. The data were collected by means of literature study and direct interviews with MSMEs actors and the regional government of Sragen Regency.

This would be very unfortunate if it was not immediately acted upon and given legal certainty of regional superior products in Sragen Regency in order to provide a legal umbrella and effort to save MSMEs' products in the region. Therefore, the researcher was interested in discussing more deeply related to geographical indications as a form of rescuing the products of MSMEs in Sragen Regency to avoid product plagiarism and claims by other competitors.

\section{DISCUSSION}

\section{The Overview of MSMEs in Sragen Regency}

Sragen Regency is one of the regencies located within the borders of Central Java Province and East Java Province with an area of $941.55 \mathrm{~km}^{2}$ which is divided into 20 sub-districts and 208 villages/ urban villages consisting of 12 urban villages and 196 villages. Astronomically and geographically, Sragen regency is located at $110^{\circ} 45^{\prime}$ $111^{\circ} 10^{\prime}$ east longitude and $7^{0} 15^{\prime}-7^{0} 30^{\prime}$ south latitude with an area of $941.55 \mathrm{~km}^{2}$ with an average height of $109 \mathrm{~m}$ above sea level. ${ }^{7}$ The regency which is known as Sukowati City has a population of 887,889 which is divided into various occupations and a population of 68,351 as MSMEs actors spread across 20 sub-districts. ${ }^{8}$

The existence of MSMEs in Sragen Regency is one of the pillars of the regional economy which is able to have a big positive impact on progress in the region. Its development is increasing every year, and based on the results in the field that the researcher obtained in the last three years, it has always experienced a significant increase. The following is the data of the number of MSMEs actors in Sragen Regency; ${ }^{9}$

\footnotetext{
${ }^{7}$ Pemerintah Daerah Kabupaten Sragen, 2016, Rencana Pembangunan Jangka Menengah Daerah Kabupaten Sragen Tahun 2016-2021, Mapcomp, Sragen, pg 1-3

${ }^{8}$ The Results of Interview with Joko Supriyanto, SST as the Executive Staff of Central Statistics Agency, Sragen Regency, on August 24th 2020

${ }_{9}^{9}$ The Results of Interview with Dewi Dwi Hastuti, SE. MM, as the Head of Micro Business Empowerment Division of Cooperative Service and MSMEs, Sragen Regency, on September $4^{\text {th }}, 2020$.
} 
Table 1. The Data of MSMEs in Sragen Regency

\begin{tabular}{cccccc} 
No & Year & Medium & Small & Micro & Total \\
\hline 1 & 2018 & 1.490 & 10.150 & 55.400 & 67.040 \\
\hline 2 & 2019 & 2.046 & 10.706 & 55.099 & 67.851 \\
\hline 3 & 2020 & 2.046 & 11.562 & 54.743 & 68.351 \\
\hline
\end{tabular}

Source: Cooperative Service and MSMEs Department, Sragen Regency

Based on the data above, it shows that the development of MSMEs actors in Sragen area always increases every year scale with nearly the same increase across all scales. From the MSMEs data, it is divided into several diverse and different business sectors, such as: agriculture, household appliances, animal husbandry, handicrafts, batik, convection, processed food, bricks, and furniture. The variety of products produced by MSMEs actors is spread throughout Sragen Sub-districts, such as: Gemolong, Masaran, Plupuh, and Gondang.

Of the many products produced by MSMEs in Sragen regency, there are several products that becomes favorites in the Sragen area, of which there are not only one but several products that have been the mascot for Sragen regency, namely: ${ }^{10}$

\section{a. Batik}

Batik is a traditional handicraft which is one of the superiorities of this region. Besides, it is one of many Indonesian cultural heritages that still survives in the markets and continues to grow from year to year. The products of batik produced are very varied and have attractive designs with distinctive flora and fauna motifs as their trademark. In Sragen regency, MSMEs actors live in two districts, namely Masaran and Plupuh with the batik products in the form of batik warna alam, batik lawasan, batik cabut, and batik malam dingin. The MSMEs actors of batik in the Sragen area already have market shares outside Sragen, such as: Surakarta, Surabaya, DKI Jakarta, and other big cities.

\section{b. Goyor Sarong}

This product, which is soft, does not wrinkle even though it is not ironed, and is cold when used in hot weather, is a handicraft product that relies on non-machine

${ }^{10}$ Supriyatno, 2014, Profil Sentra Industri Kecil Menengah (IKM) Kabupaten Sragen, Dekranasda Press, Sragen, pg 19-35 
looms. It can be found in Kalijambe Sub-district and has its own superiority such as its historical value because it is a handmade product produced from generation to generation so it has an ancestral heritage potential that should be preserved in Sragen Regency. This Goyor Sarong Crafts are well known in several countries in Middle East, such as: Somalia, Yemen, and Egypt.

\section{c. Handicrafts}

Another interesting superior product in Sragen Regency is handi products made of fossil stones found in Sangiran Prehistoric Museum. These handicrafts have special characteristic because they are very unique, formed from natural factors and humans. The handicraft products are in the form of sculptures, statues, agates, replicas of ancient humans, replicas of ivory, and replicas of animals. The handicrafts of MSMEs in Sragen are only sold in the Sangiran Prehistoric Museum area because the authenticity and genuineness of the materials are still preserved and are only made by the Sangiran community, not in other sub-districts.

Based on the description above, the MSMEs' superior products in Sragen Regency which have the potential to be given legal protection through geography is Sangiran's fossil stone handicrafts in Kalijambe District. The results of Sangiran fossil handicraft products are unique compared to other products that have been on the market so far. The existence of Sangiran MSMEs actors has been around since 1985 and has consistently been up to now by providing a variety of very unique and attractive products for consumers outside the Sragen area. The MSMEs' products of Sangiran's fossil handicrafts were formed due to the combination of natural and human factors with good reputation, characteristics, and quality to give more added value. The main materials used are the remains of fossils and stones around the Museum of Early Man while the craftsmen are the native people from around the museum.

Sangiran's fossil handicrafts are formed from fossil remains and stones with special characteristics, quality, and reputation that have economic value. When broken down, the fossils or stones have a very beautiful natural color by emitting motives in the form of striated lines and batik. So, from the aspect of the characteristics of the raw material for Sangiran's fossil crafts, they are fulfilled. For the aspect of product quality, Sangiran's fossil handicrafts have various forms with useful and aesthetic functions, such as; the replicas of ivory, ancient humans, animals; and ashtrays, carnelian, necklaces, prayer beads, and smoking pipes. The reputation of Sangiran's fossil handicrafts is shown by the existence of the Sangiran Archaeological Museum area which is the center of ancient human civilization in Indonesia and its location is surrounded by MSME's craftsmen of Sangiran's fossil in Kalijambe District, Sragen Regency. ${ }^{11}$

${ }^{11}$ The Results of Interview with Suratno, S.H, as the Section Head of Agro Industry, Forest Products and Energy and Mineral Resources of the Industry and Trade Office of Sragen Regency, on December $3^{\text {rd }}, 2020$. 
Even though Sragen regency has many superior products produced by local MSMEs actors, it does not guarantee that with the increasing number of actors in the area, more and more people are aware of the law and willing to register the products produced by law legality registration through intellectual property rights (IPR). This condition is due to various factors that become obstacles, not only from the human resources but also from the less optimal role of the local government. The various educational levels of business actors, low information related to legality management, and limited knowledge, and lack of attention from the local government are some of the aspects that hinder MSMEs actors in obtaining and registering legality of the products they produce.

It is true that in Sragen Regency, many MSMEs actors have not received legal protection related to business legality, such as: Trademarks, label of Halal, Industrial Design, Company Business License, Industrial Registration Certificates, and MSMEs License. This is confirmed by the licensing officer of One-Door Integrated Investment Service, Sragen Regency that the number of MSMEs registered in the government database is still very small and the following is the number of MSMEs in Sragen Regency in the last three years: ${ }^{12}$

Table 2 The Data of Licensed and Unlicensed MSMEs in Sragen Regency

\begin{tabular}{lcccc} 
No & Year & Licensed & Unlicensed & Total \\
\hline 1 & 2018 & 864 & 66.176 & 67.040 \\
\hline 2 & 2019 & 2.558 & 65.293 & 67.851 \\
\hline 3 & 2020 & 4.994 & 63.357 & 68.351 \\
\hline
\end{tabular}

Source: One-Door Integrated Investment Service Departement, Sragen Regency

Looking at the description of the data above, it shows that the awareness of MSMEs actors in Sragen Regency is still low seen from the total number of MSMEs actors who have obtained business licenses and who have not registered the products produced through business legality. The existence of business legality seems to have not made a big contribution to MSMEs actors so that many business actors are reluctant to register their products through licensing at local institutions. Whereas, licensing plays a vital role in long-term business development, helping in the marketing process which makes it easier to open new market shares and to anticipate unfair business competition.

On the other hand, registering business legality is similar with having a good impact on the local government. One of which is increasing the source of regional income in

12 The Results of interview with Sri Umiyarsi, S.E, as the Head of Licensing Section of One-Door Integrated Investment Service, Sragen Regency, on September $7^{\text {th }}, 2020$ 
Sragen Regency and being able to support development financing in Sragen Regency. In addition, by registering the legality of the business, the community or MSMEs actors are obtaining legal certainty, certainty of rights, and other facilities that support the business after the building has its license. ${ }^{13}$ It is very unfortunate if there are still many MSMEs actors in Sragen who have not received a definite legal umbrella so that in order to secure and avoid bad actions, in this case the roles of government, stakeholders, and society are to unite the vision and mission so that MSMEs are aware of the law, have wide market access, and have high competitiveness in the market, both nationally and internationally.

\section{The Development of Geographical Indications in Indonesia}

Geographical indication is a part of the elements of intellectual property rights which are divided into several aspects, such as trademarks, patents, industrial designs, trade secrets, and integrated circuit layout designs. ${ }^{14}$ Apart from the peculiarity of the geographical area factor, geographical indication is also a communal right due to its collective subjective nature and untransferability to other people. ${ }^{15}$ The presence of geographic indications for the first time was the Agreement of Trade Related Aspect of Intellectual Property Rights (TRIPs) in 1994 and Law Number 7 of 1994 concerning Ratification of the Agreement Establishing the World Trade Organization which states that countries that are members of and participate in the agreement must establish regulations related to legal protection of intellectual property rights (IPR) of brands and geographic indications. This is a clear evidence of the seriousness of the Indonesian State in handling intellectual property rights (IPR). ${ }^{16}$

Geographical indications in Indonesia was initially marked by the emergence of new rules of Law Number 15 of 2001 concerning Trademarks, Government Regulation Number 51 of 2007 concerning Geographical Indications and the latest amendments to the previous regulations, namely Law Number 20 of 2016 concerning Trademarks and Geographical Indications which until now has become a guideline regarding the management of trademarks and geographic indications in Indonesia. Since the issuance of regulations related to geographic indications to date in Indonesia, it has reached the number 92 products of MSMEs actors that have been registered in the National Geographical Indication and spread throughout Indonesia from 2008 to $2020 .{ }^{17}$ The following is the development of geographical indication registration in the last three years from 2017 to $2019 ;^{18}$

\footnotetext{
${ }^{13}$ Adrian Sutedi, 2011, Hukum Perizinan Dalam Sektor Pelayanan Publik,: Sinar Grafika, Jakarta, pg. 200

${ }^{14}$ Winda Risna Yessiningrum, Perlindungan Hukum Indikasi Geografis Sebagai Bagian Dari Hak Kekayaan Intelektual, Jurnal Hukum dan Keadilan IUS Vol. III No. 7 (2015), pg 44

${ }^{15}$ Rahmi Jened, 2015, Hukum Merek (dalam Global \& Integrasi Ekonomi), Kencana, Jakarta, Pg. 269-270

${ }^{16}$ Safril Sofwan Sanib, Ketentuan-ketentuan TRIPS-Plus dalam Kerangka Perjanjian Perdagangan Bebas, Jurnal Hukum Holrev Vol. III No. 1 (2019), pg 51

${ }^{17}$ Direktorat Jendral Kekayaan Intelektual (DJKI), Listing Indikasi Geografis Terdaftar, http://ig.dgip.go.id/ accessed on September 11 $11^{\text {th }}, 2020$.

${ }^{18}$ Direktorat Jendral Kekayaan Intelektual (DJKI), Statistik Permohonan Permohonan Lain Berdasarkan Jenis, https://statistik.dgip.go.id/statistik/production/lain_jenis.php accessed on September $19^{\text {th }}, 2020$
} 
Table 3 The Number of applications for Intellectual Property Rights in Indonesia

\begin{tabular}{ccccccc} 
& & \multicolumn{5}{c}{ Types of Applications } \\
No & Year & Trademarks & Patents & $\begin{array}{r}\text { Industri- } \\
\text { al Designs }\end{array}$ & $\begin{array}{c}\text { Geographical } \\
\text { Indications }\end{array}$ & $\begin{array}{r}\text { Trade } \\
\text { secrets }\end{array}$ \\
\hline 1 & 2017 & 53.105 & 986 & 3.656 & 15 & 0 \\
\hline 2 & 2018 & 52.351 & 1.542 & 3.812 & 35 & 0 \\
\hline 3 & 2019 & 22.659 & 568 & 1.733 & 4 & 0 \\
\hline
\end{tabular}

Source: primary data that is processed

Viewed from the data above, the number of applicants for geographical indications in Indonesia is still very low compared to trademarks, patents, and industrial designs, whereas in 2018 the Directorate General of Intellectual Property Rights stated that 2018 was the year for geographical indications, ${ }^{19}$ in which each regency/ district in Indonesia immediately registered the products that have the potential to be protected with geographical indications at the nearest Law and Human Rights office. However, the reality is that up to now not many regencies/ districts have been moved to register their superior products in the region through geographical indications. Conditions like this are due to various problems that are very different in each regency/ district, so there is no definite reference regarding the main problem that is the basis for delays in managing geographic indications in each regency/ district.

Seeing conditions like this, the government should be more active in socializing the regulations related to geographical indications to pay close attention because products that have the potential for geographic indications can become regional assets that make a big contribution to the progress and increase of per capita income in the region. On the other hand, registering products that have superior potential with geographic indications can provide great benefits for MSMEs actors in areas such as: ${ }^{20}$

a. Protecting the products and the manufacturers

Products that have been registered with geographic indications can directly provide security to the registered products and the manufacturers or MSMEs craftsmen so they can be protected from fraud, misuse, and falsification of geographic indication signs of the registered products.

b. Increasing the bargaining position of the products in the market.

\footnotetext{
${ }^{19}$ Freddy Harris, Dirjen Kekayaan Intelektual Canangkan Program Tahun Indikasi Geografis di Indonesia, https://dgip.go.id/ dirjen-ki-canangkan-program-tahun-indikasi-geografis-di-indonesia accessed on August $20^{\text {th }}, 2020$

${ }^{20}$ Direktorat jenderal Kekayaan Intelektual (DJKI), 2015, Indikasi geografis Indonesia, DJKI Press, Jakarta, pg. $9-10$
} 
Products have advantages and special characteristics formed due to natural or human factors. If they are protected by geographical indications, the products will increase their position in the market, have their own space, increase their price, and have the ability to enter new markets easily at both national and international levels .

c. Increasing the added value

Products that are registered with a geographic indication will automatically increase the value of the product, which is not only from the quality of the product but also the increase of the productionand the opportunity formoreattractive productdiversification with new and different innovations.

d. Providing clear information to consumers

All kinds of products protected by the right law, not only geographical indications but also other terms, will provide clear detailed information to consumers. In this case, not only the names of the products but the geographical indications, the information are more detailed such as: type of product, quality, and origin of the product produced. The origin of products is what is different and superior to other business legality.

e. Increasing promotion opportunities

Products that already have clear legality will directly open their own opportunities easilyintheirpromotioninnewmarketsegments.Becauseofthegeographicalindications, the product is guaranteed and the general public does not hesitate in promoting and using the product.

f. Increasing income and welfare

Products that have been registered with geographical indications are guaranteed to use.Besides, MSMEs actors cangetsomebenefits, for example:profitsgeneratedincrease than before and they are able to provide better welfare for their own manufacturers.

g. Improvign the economy and accelerate regional development

In addition to being able to provide more income for MSMEs, geographic indications are also able to contribute to the improvement of the regional economy because the taxes given indirectly play a role in supporting the acceleration of regional development in regency/ district.

h. Maintaining environmental sustainability

Basically, the protection of geographic indications is not only to guarantee the safety of the registered products, but also to guarantee and maintain the authenticity of the characteristics and qualities of the products as long as the character of the products is not reduced or lost.

i. Maintaining the preservation of the nation's culture

The validity period of geographic indications is not limited by time guided by the quality of the products resulted. So, the geographicindication products can continuously increase the reputation of the products in the market and help to preserve the culture of Indonesian nation. 
From the description above, it turns out that legal protection through geographical indications has many benefits not only for MSMEs, local governments, stakeholders, and the surrounding communities. For this reason, Sragen Regency should register one of the superior products in the area so that the products in the Sragen Regency area can have high competitiveness and be accepted in the national and international markets. Given the role of geographical indications is very vital in long-term business competition and maintaining safety, the authenticity of products in Sragen regency is needed.

\section{Geographical Indication as a Rescuer for MSMEs' Products in Sragen Regency}

Geographical Indication is a sign indicating the origin of a good and/or product due to geographical environmental factors including natural factors, human factors, or a combination of these two factors that give certain reputation, quality, and characteristics to the goods and/or products made. ${ }^{21}$ Besides, geographical indication is a sign used on products that have a specific geographical origin and possess qualities or a reputation that are due to that origin. In order to function as a geographical indication, a sign must identify a product as originating in a given place. ${ }^{22} \mathrm{~A}$ geographical indication identifies a good as originating in a specific region where a particular quality, reputation or other characteristic of the good is essentially attributable to that geographic origin. ${ }^{23}$

From the definitions above, geographical indications are signs used by the products that have a certain geographical origin and a quality or reputation due to the origin of the goods. Geographical indication identifies goods originating from a certain area with the quality, reputation, or other characteristics of the goods related to that geographical origin. So, the meaning of geographic indication is a sign of a product/ service that has special characteristics that indicate the origin of the area the product made. In this case, the products that can be protected by geographical indications are natural resources, handicrafts, and industrial products so that products that are not related to these three aspects cannot be registered through geographical indications because they are out of the specified conditions. ${ }^{24}$

The principle of good governance in the implementation of regional government is a demand for local government to create a transparent, clean, and democratic governance. ${ }^{25}$ The Regional Government of Sragen Regency is given an authority to develop its area according to its potentials and superiorities, but it needs to be synchronized with the direction of industrial development, which includes the determination of the leading

\footnotetext{
${ }^{21}$ Article 1, paragraph 6 of Law Number 20 of 2016 concerning Trademarks and Geographical Indications

22 Francis Gurry, Geographical Indications, https://www.wipo.int/geo_indications/en/\#: :text = A \% 20geographical \% 20indication \% 20(GI) \% 20is,originating \% 20in \% 20a \% 20given \% 20place accessed on August $27^{\text {th }}, 2020$

${ }_{23}$ Alex Converga, It all has to do with geographical indications, https:/www.ipaustralia.gov.au/trade-marks/ understanding-trade-marks/types-trade-marks/certification-trade-mark/geographical accessed on August $20^{\text {th }}, 2020$

${ }^{24}$ Article 53, paragraph 3 of Law Number 20 of 2016 concerning Trademarks and Geographical Indications

${ }^{25}$ Yulia Neta, Model Tata Kelola Administrasi Pemerintahan Yang Baik di Daerah Otonom Baru, Fiat Justitia Jurnal Ilmu Hukum, Vol. 6 No. 2 (2012), pg. 2
} 
industries in the regency/ district. ${ }^{26}$ So far, the regional government has determined the leading industry as an effort to explore deeper regional potentials as well as to promote regional activities, namely Batik products, Goyor sarong, and Handicrafts. The third product was chosen to be the superiority in Sragen Regency because it has special characteristics that can give a big contribution to Sragen area compared to other products.

Three products produced by MSMEs actors in Sragen Regency which have special characteristics and different characters from the others are handicrafts of Sangiran stone fossils in Kalijambe Sub-district. Sangiran fossil stone handicraft products are formed due to natural and human factors, so the main raw materials used are stone fossil of Sangiran museum which only exist in the Kalijambe area and these products are traditionally made by the people around Sangiran so that these products are created due to a combination of those factors. If it is related to Article 1 paragraph 6 , geographic indication products are formed due to natural factors, humans factors, or their combination that give reputation and special characteristics, so from the statement, it can be concluded that the products of Sangiran fossil stone handicrafts can be registered and protected by geographical indications.

These fossil stone handicrafts sell the value of carving, which tells some stories or duplicates miniatures of ancient human sculptures, ivory, and various animals using traditional tools. ${ }^{27}$ This craft is located in Kalijambe Subdistrict with 60 MSMEs actors who have a limited market share. ${ }^{28}$ Sangiran MSMEs' handicraft products can be registered through geographical indications which do not contradict the state ideology, laws and regulations, religion, morality, and public order; and do not mislead or deceive the public regarding their reputation, quality or characteristics. ${ }^{29}$ The applications for geographic indications of fossil stone handicraft products were also not rejected because they could be proven true and had no similarity to all geographic indications that had been previously registered. ${ }^{30}$

With the explanation above, MSMEs' fossil stone handicraft products are very prospective to be protected with the legality of geographical indications. Besides having superior potential in Sragen area, these products also meet the criteria to be registered through geographic indications. So, if registered there will be a lot of feedbacks received by the business actors, the local government and the surrounding communities. Basically, legality is the main weapon in selling or marketing products because it can be an attraction and a key to the success of these products in order to be accepted by

\footnotetext{
${ }^{26}$ Article 13, paragraph 2 of Law Number 32 of 2004 concerning Local Government Regulation.

${ }^{27}$ Humas Pemerindah Daerah (PEMKAB) Kabupaten Sragen, Industri Batu-Batuan, http://www.sragenkab. go.id/backup-1/statis-71-perindustrian.html accessed on September $1^{\text {st }}, 2020$

${ }_{28}$ The Results of interview with Fajar Ari as the Executive Staff of Sragen MSMEs, Kalijambe Sub-district, Sragen Regency, on September $11^{\text {th }}, 2020$

${ }^{29}$ Article 56, paragraph 1 of Law Number 20 of 2016 concerning Trademarks and Geographical Indications

${ }^{30}$ Article 56, paragraph 2 of Law Number 20 of 2016 concerning Trademarks and Geographical Indications
} 
consumers. Legality is an important point because the benefits obtained for MSMEs greatly influence the continuity of their business. Besides, the urgency of business legality for MSMEs are as follows; ${ }^{31}$

a. As a legal base

In fact, any activity cannot be carried out by MSMEs or the community without a legality from the authorized government or related stakeholders. Without legality, MSMEs actors do not have a definite basis or reference in the continuity of the business being carried out, because there is no official recognition from the authorized party.

b. As an instrument to protect public interests and ensure legal certainty.

Basically, legality is formed from various subjective and objective aspects, for example in such legality, it contains the identity of the business actors, so the person concerned has the right to carry out activities with the limitation of location, volume, or other related things that are objective. Besides, legality can be used as an instrument to protect the interests of the applicants, the government, and others.

c. As an evidence in terms of claims

Legality, in this case, can be used by business actors as an evidence stating that MSMEs actors have received recognition from the local government. So, when a legality problem occurs, it can be used as evidence in solving the problem.

Thus, the ownership of legality for MSMEs actors has enormous urgency in running their business, because the impact and usefulness of legality is very supportive for the success of business actors in the region. On the other hand, the role of the industrial sector as a driving force of the economy also occurs in Sragen Regency. ${ }^{32}$ It can be shown by the contribution of the industrial sector in Sragen Regency to the GRDP (Gross regional domestic product) of Sragen Regency with an average of $35.45 \%$ during the period 2010-2019..$^{33}$ From these data, it can be concluded that the existence of MSMEs actors is able to make a large contribution to the regional per capita income, so the enthusiasm from the government, stakeholders, and community is very much needed to support the regional MSMEs actors to develop and provide a legal umbrella for product commodities, as well as to be an alternative for product marketing of geographical indications in domestic or foreign trade transactions. ${ }^{34}$

In addition, giving a legality through geographical indications of one of the superior products with high potential in Sragen Regency is one of the best solutions for the safety of MSMEs actors in the Regency and for saving potential products in the area,

\footnotetext{
${ }^{31}$ M. Iqbal Damanik, 2016, Penyederhanaan Perizinan Usaha Di Daerah, KPPOD Media, Jakarta, Pg 6

${ }^{32}$ Bidang Perindustrian, 2018, Kajian Penetapan Industri Prioritas Untuk Penyusunan RPIK Kabupaten Sragen, Amanah Offset, Sragen, pg 2-3

${ }^{33}$ Humas BPS Sragen, Distribusi Persentase PDRB Kab. Sragen Atas Dasar Harga Konstan 2010 Menurut Lapangan Usaha 2010-2019, https://sragenkab.bps.go.id/statictable/2020/03/01/429/distribusi-persentase-pdrb-kabupatensragen-atas-dasar-harga-konstan-2010-menurut-lapangan-usaha-2010---2019-persen-.html accessed on August 21 2020

${ }_{34}$ Ayup Suran Ningsih, dkk. Indikasi Geografis atas Carica Dieng Sebagai Strategi Penguatan Ekonomi Daerah, Jurnal Suara Hukum, Vol. 1, No. 1 (2019), pg.109.
} 
because based on Law Number 20 of 2016 concerning Trademarks and Geographical Indications, Sangiran's fossil stone handicraft products have great potential in the long term because the benefits obtained for the future are very positive and can preserve and maintain the reputation of the Sangiran area which is a valuable asset in Sragen Regency. ${ }^{35}$ In addition, the law protection of the geographical indications can prosper the surrounding communities and farmers if the local government can optimize its role through the development and monitoring of the geographical indications. ${ }^{36}$

The use of geographic indications as an alternative to save regional products in Sragen Regency is also a form of protection for MSMEs in the region, which is in accordance with one of regional government policies contained in regional regulations by maintaining fields and types of activities that are labor intensive, and have specific processes and values of arts and cultures that is special and hereditary and/or regional characteristics. ${ }^{37}$ It shows that saving Sangiran's fossil stone handicraft products is a wise and appropriate step in accordance with applicable regulations and it can help Sragen Regency government in securing its regional potential products through the legal umbrella of geographical indications. Besides, it is also a form of guidance to provide legal advocacy and defense of business opportunities for MSMEs in Sragen Regency. ${ }^{38}$

\section{CONCLUSION}

The registration of geographic indications towards one of the potential products in Sragen regency is the right action, because this step has a good long-term positive impact that not only saves the products of MSMEs actors in the region but also provides a lot of feedbacks for the government, the stakeholders, the comunities, and the actors themselves. The impacts achieved by registering the geographic indications are; it can protect the products and the manufacturers, increase the bargaining position of the products in the market, increase the added value, provide clear information to consumers, increase promotional opportunities, increase income and welfare, increase the economy and accelerate regional development, and preserve the environment and culture of the Indonesian nation. On the other hand, the rescue effort of regional potential products in Sragen Regency through geographical indications is a form of legal protection in accordance with the mandate of Regional Regulation of Sragen Regency Number 3 of 2013 concerning the MSMEs.

\footnotetext{
35 Annisa Ambadar, Indikasi Geografis sebagai Indikasi Reputasi, Kualitas dan Karakteristik https://ambadar. co.id/geographical-indication/indikasi-geografis-sebagai-indikasi-reputasi-kualitas-dan karakteristik/ accessed on August $19^{\text {th }}, 2020$

${ }^{36}$ M. Rendi Aridhayandi, Peran Pemerintah Daerah Dalam Pelaksanaan Pemerintah Yang Baik (Good Governance) Dibidang Pembinan dan Pengawasan Indikasi Geografis, Jurnal Hukum \& Pembangunan 48 No. 4 (2018), pg 900

${ }^{37}$ Article 8, section f of Sragen Regency Regional Regulation Number 3 of 2013 concerning Micro, Small and Medium Enterprises (MSMEs)

${ }_{38}$ Article 15, section d of Sragen Regency Regional Regulation Number 3 of 2013 concerning Micro, Small and Medium Enterprises (MSMEs)
} 


\section{REFERENCES}

\section{Books}

Adrian Sutedi, (2011), Hukum Perizinan Dalam Sektor Pelayanan Publik,: Sinar Grafika, Jakarta.

Badan Pusat Statistik, (2020), Sragen Dalam Angka Tahun 2020 (Sragen Regency in Figures), Badan Pusat Statistik (BPS) Press, Sragen.

Bidang Perindustrian, (2018), Kajian Penetapan Industri Prioritas Untuk Penyusunan RPIK Kabupaten Sragen, Amanah Offset, Sragen.

Direktorat jenderal Kekayaan Intelektual/DJKI, (2015), Indikasi geografis Indonesia, DJKI Press, Jakarta.

M. Iqbal Damanik, (2016), Penyederhanaan Perizinan Usaha Di Daerah, KPPOD Media, Jakarta.

Pemerintah Daerah Kabupaten Sragen, (2016), Rencana Pembangunan Jangka Menengah Daerah Kabupaten Sragen Tahun 2016-2021, Mapcomp, Sragen.

Rahmi Jened, (2015), Hukum Merek (dalam Global \& Integrasi Ekonomi), Kencana, Jakarta.

Saky Septiono, (2009), Perlindungan Indikasi Geografis dan Potensi Indikasi Geografis Indonesia, Subdit Indikasi Geografis Dijten HKI ; Kementerian Hukum dan HAM RI, Jakarta.

Supriyatno, (2014), Profil Sentra Industri Kecil Menengah (IKM) Kabupaten Sragen, Dekranasda Press, Sragen.

\section{Journal and other scientific reference}

Ayup Suran Ningsih dkk, Indikasi Geografis atas Carica Dieng Sebagai Strategi Penguatan Ekonomi Daerah, Jurnal Suara Hukum, Vol. 1, No. 1 (2019).

M. Rendi Aridhayandi, Peran Pemerintah Daerah Dalam Pelaksanaan Pemerintah Yang Baik (Good Governance) Dibidang Pembinan dan Pengawasan Indikasi

Geografis, Jurnal Hukum \& Pembangunan 48 No. 4 (2018).

Safril Sofwan Sanib, Ketentuan-ketentuan TRIPS-Plus dalam Kerangka Perjanjian Perdagangan Bebas, Jurnal Hukum Holrev Vol. III No. 1 (2019).

Winda Risna Yessiningrum, Perlindungan Hukum Indikasi Geografis Sebagai Bagian Dari Hak Kekayaan Intelektual, Jurnal Hukum dan Keadilan IUS Vol. III No. 7 (2015).

Yulia Neta, Model Tata Kelola Administrasi Pemerintahan Yang Baik di Daerah Otonom Baru, Fiat Justitia Jurnal Ilmu Hukum, Vol. 6 No. 2 (2012).

\section{Regulations}

Sragen Regency Regional Regulation Number 3 of 2013 concerning Micro, Small and Medium Enterprises (Regional Gazette of Sragen Regency of 2013 Number 3, Supplement to the Regional Gazette of Sragen Regency Number 3)

Law Number 32 of 2004 concerning Local Government Regulation (State Gazette of the Republic of Indonesia of 2004 Number 125, Supplement to the State Gazette of 
the Republic of Indonesia Number 4437)

Law Number 20 of 2016 concerning Trademarks and Geographical Indications (State Gazette of the Republic of Indonesia of 2016 Number 252, Supplement to the State Gazette of the Republic Indonesia of Number 5953)

\section{Website}

Alex Converga, It all has to do with geographical indications, h $\mathrm{t} t \mathrm{p} \mathrm{s}:$ / / w w w . ipaustralia.gov.au/trade-marks/understanding-trade-marks/types- $\mathrm{t}$ r a d e marks/certification-trade-mark/geographical accessed on August 22 ${ }^{\text {nd }}$, 2020

Annisa Ambadar, Indikasi Geografis sebagai Indikasi Reputasi, Kualitas dan Karakteristik https://ambadar.co.id/geographical-indication/indikasigeografis- sebagai-indikasi- reputasi-kualitas-dan-karakteristik/ accessed on August $19^{\text {th }}, 2020$.

Direktorat Jendral Kekayaan Intelektual (DJKI), Listing Indikasi Geografis Terdaftar, http://ig.dgip.go.id/ accessed on September 11 $1^{\text {th }}, 2020$.

Direktorat Jendral Kekayaan Intelektual (DJKI), Statistik Permohonan Permohonan Lain Berdasarkan Jenis, https://statistik.dgip.go.id/statistik/production/lain_ jenis.php_ accesed on September $19^{\text {th }}, 2020$

Humas BPS Sragen, Distribusi Persentase PDRB Kab. Sragen Atas Dasar Harga Konstan 2010 Menurut Lapangan Usaha 2010-2019, https://sragenkab.bps.go.id/statictable/2020/03/01/429/distribusi-persentasepdrb kabupaten-sragen-atas-dasar-harga-konstan-2010-menurut-lapanganusaha-2010--- 2019-persen-.html accessed on August 29 ${ }^{\text {th }}, 2020$

Humas Pemerindah Daerah (Pemkab) Kabupaten Sragen, Industri Batu-Batuan, http://www.sragenkab.go.id/backup-1/statis-71-perindustrian.html accessed on September $1^{\text {st }}, 2020$

Francis Gurry, Geographical Indications https://www.wipo.int/geo_indications/ en/\#: :text = A \% 20geographical\%20indicati o n \% 20 ( G I ) \% 20 is,originating \% 20in \% 20a \% 20given \% 20place accessed on August 27 $7^{\text {th }}, 2020$

Freddy Harris, Dirjen Kekayaan Intelektual Canangkan Program Tahun Indikasi Geografis di Indonesia, https://dgip.go.id/dirjen-ki-canangkan-program-tahun-indikasigeografis-di- indonesia accessed on August $20^{\text {th }}, 2020$

\section{Interviews}

The Results of Interview with Supat, SE as the Section Head of Cooperative Division, Cooperative Service and MSMEs, Sragen Regency, September $1^{\text {st }}, 2020$.

The Results of Interview with Suhari, SH as the Section Head of Licensing at the Office of One-Door Integrated Investment Service, Sragen Regency, September $3^{\text {rd }}$, 2020 .

The Results of Interview with Sukoco as MSMEs actor in Sangiran, Kalijambe District, Sragen Regency, December 3rd, 2020.

The Results of interview with Bambang as the Head of Association Cooperative, Sragen MSMEs, Kalijambe Sub-district, Sragen Regency, on September $14^{\text {th }}, 2020$ 
The Results of Interview with Joko Supriyanto, SST as the Executive Staff of Central Statistics Agency, Sragen Regency, on August 24 ${ }^{\text {th }}, 2020$

The Results of Interview with Dewi Dwi Hastuti, SE. MM, as the Head of Micro Business Empowerment Division of Cooperative Service and MSMEs, Sragen Regency, on September $4^{\text {th }}, 2020$

The Results of Interview with Sri Umiyarsi, S.E, as the Head of Licensing Section of One-Door Integrated Investment Service, Sragen Regency, on September $7^{\text {th }}$, 2020.

The Results of Interview with Suratno, S.H, as the Section Head of Agro Industry, Forest Products and Energy and Mineral Resources of the Industry and Trade Office of Sragen Regency, on December 3rd, 2020.

The Results of Interview with Fajar Ari as the Executive Staff of Sragen MSMEs, Kalijambe Sub-district, Sragen Regency, on September 11 ${ }^{\text {th }}, 2020$ 